\title{
State Welfare Policies and Children's Living Arrangements
}

\author{
Rachel Dunifon \\ Cornell University \\ Kathryn Hynes \\ Pennsylvania State University \\ H. Elizabeth Peters \\ Cornell University
}

\begin{abstract}
Changes in welfare legislation throughout the 1990s attempted, among other things, to promote marriage and decrease single parenthood. However, little research considers how such policies influence children's living arrangements. This article uses data from the Survey of Income and Program Participation to relate welfare reform policies to the likelihood that children live in one of three living arrangements: with married parents, with a single parent, or with a parent and another adult. Unlike previous work, the study differentiates the ways in which various types of Temporary Assistance for Needy Families (TANF) policies, such as time limits, sanctions, and income disregards, predict children's living arrangements. Overall, results show very few robust associations between welfare policies and children's living arrangements.
\end{abstract}

In 1996, Congress passed and President William Clinton signed the Personal Responsibility and Work Opportunity Reconciliation Act (PRWORA; U.S. Public Law 104-193), which abolished the Aid to Families with Dependent Children (AFDC) program and established instead a system of Temporary Assistance for Needy Families (TANF). The legislation explicitly promoted work and marriage, identifying the reduction of single parenthood as a key goal. The assumption was that resulting changes would benefit children.

In actuality, even before the 1996 PRWORA legislation, the federal

Social Service Review (September 2009).

(C) 2009 by The University of Chicago. All rights reserved.

0037-7961/2009/8303-0002\$10.00 
government gave states extensive leeway to opt out of AFDC system requirements and to develop their own welfare policies. Many of these state policies were precursors to TANF; among them were work requirements, stringent child support enforcement provisions, and rules that increased the eligibility of married-couple families for cash assistance. Most of these changes occurred during the early and mid-1990s. By 1996, 27 states implemented a major welfare waiver of some kind (reviewed in Schoeni and Blank 2000), though the welfare requirements specified by these waivers varied greatly across states.

During congressional debate over the 1996 legislation, much of the rhetoric focused on the need to reduce single parenthood and increase marriage, but most of the policies implemented by states during the 1990s focused instead on increasing employment and decreasing welfare use (some policy exceptions include the implementation of the family cap and efforts to expand public assistance eligibility for married couples, described below). As described further below, changes in welfare policies could influence living arrangements both directly and indirectly. This article thus examines whether the welfare changes that occurred during the 1990s, both before and after the implementation of TANF, are associated with children's living arrangements. It uses data from the Survey of Income and Program Participation (SIPP) for the years 1992-99. ${ }^{1}$

\section{Living Arrangements and Child Well Being}

A considerable body of research examines whether living with a single parent is detrimental for children. In general, this research suggests that such children, on average, fare worse than those living with married parents; they have a greater number of behavior problems, higher rates of teenage pregnancy, and lower levels of academic achievement (McLanahan and Sandefur 1994). The influence of living with a single parent also appears to extend into adulthood. For example, a recent study finds that men who grow up in father-absent households have higher rates of incarceration than men who grow up living with both biological parents (Harper and McLanahan 2004). Research by Sara McLanahan and Gary Sandefur (1994) finds that living with a single parent is also associated with unemployment and public assistance use in adulthood.

However, there is some evidence that single parenthood may not be associated with reduced well being for minority children or those in low-income families. For example, one study finds that duration of time spent living with a single mother is associated with reductions in test scores and delinquency among white children but not African American children (Dunifon and Kowaleski-Jones 2002). Another study, which examines a sample of low-income children, finds very few associations 
between living arrangements and child development (Foster and Kalil 2007). Finally, various other studies find that, after controlling for an extensive range of maternal and child characteristics, the outcomes of children in single-parent families do not differ to a statistically significant degree from those of children in married-parent families (Carlson and Corcoran 2001; Ginther and Pollak 2004; Gennetian 2005; Foster and Kalil 2007). In sum, although most researchers agree that living arrangements are linked to children's outcomes, some evidence suggests that this link may not be as strong as originally thought.

\section{How Might State Policy Choices Influence Children's Living Arrangements?}

There are several routes through which changes in welfare policies may influence children's living arrangements. Welfare reform is likely to have direct effects on welfare use (actual or anticipated), welfare payments, employment, and income. These changes in employment and financial resources may, in turn, influence children's living arrangements in various ways. Direct incentives to marry also may prompt changes in living arrangements. Although this study does not examine women's childbearing decisions, it is possible that welfare reform could influence the decision to have children as well as the relationship context in which a birth occurs.

Several scholars have elucidated the pathways through which welfare policy changes could influence children's living arrangements (Peters, Plotnick, and Jeong 2003; Grogger and Karoly 2005). If the attractiveness of welfare declines due to reductions in benefits or increases in the strictness of work rules and enforcements, marriage (as well as cohabitation or living with other adults) could increase, because mothers may feel the need to turn elsewhere for the financial support they no longer can or want to obtain from the welfare system. In other words, women may find a substitute for welfare in marriage or doubling up with other adults. If changes in welfare policies increase the accessibility of welfare to married parents, a previously existing barrier to marriage is removed, and marriage rates may rise. Welfare policies also may promote increases in earnings or income by increasing the amount of earnings that women can keep or by pushing women into the labor market. These behavioral changes could lead to an increase in marriage if, due to their improved financial status, women become more attractive spouses. Additionally, existing marriages may be less likely to dissolve if improved financial situations diminish strain within a relationship. However, if a woman's financial position improves, her chances of marriage and cohabitation may decrease, as she may use her financial independence to live on her own. 
This article examines six types of welfare policies that changed during the 1990s and that may indirectly or directly affect living arrangements: time limits, sanctions, income disregards, paternity establishment, eligibility of married couples for welfare, and family caps. These policy measures represent only some of the many choices available to states but are consistent with the key policy variables examined by other researchers as well as with those most likely to influence living arrangements (Grogger and Karoly 2005). The discussion below describes each policy change and outlines how it may influence living arrangements.

Time Limits

One of the most dramatic changes in welfare policy in the 1990s was the imposition of time limits on the receipt of public assistance. During the mid-1990s, waivers from the federal government allowed several states to limit the amount of time recipients could receive cash assistance. The 1996 legislation included a 5-year maximum lifetime limit on the receipt of federally funded welfare benefits. State variation still persists, because some states chose to use their own funds to avoid imposing time limits. Other states set time limits that are even stricter than those established by the federal guidelines.

In general, time limits are likely to decrease welfare use and increase employment but to have ambiguous effects on total household income (Grogger and Karoly 2005). These changes, in turn, could influence living arrangements in the ways noted above. It is important to note that this study only includes data through 1999 and thus covers a period before many families reached the federal (and perhaps the state) time limits. However, some research indicates that time limits influence recipients' behavior well before they are imposed because they indicate to recipients that welfare will not continue indefinitely. One study finds that recipients leave welfare for employment before the limit is reached, departing from the rolls in order to retain some welfare eligibility for a later date (Grogger and Michalopoulos 2004). Strict time limits may also lead women to marry or double up in order to buffer against future losses of welfare support.

\section{Sanctions}

In the years before PRWORA, 21 states received federal waivers allowing them to reduce or eliminate benefits for welfare participants who did not meet the work requirements of the Job Opportunity and Basic Skills Program (JOBS, a pre-TANF welfare-to-work program; Grogger and Karoly 2005). Under PRWORA, welfare recipients must participate in work or work-related activities in order to receive public assistance, and states use sanctions to enforce this policy. Although sanctions are part of the PRWORA legislation, there is variation in the severity of the 
sanctions imposed by states. Sanctions range from partial- to full-benefit reductions of welfare benefits. Sanctions may indirectly affect family arrangements, as they are likely to decrease welfare use, increase employment, and have an ambiguous effect on total income (Grogger and Karoly 2005).

\section{Income Disregards}

Under AFDC, all recipients who worked were entitled to exclude as a work expense the first $\$ 90$ of their earnings when calculating their benefit levels. This exclusion, which effectively raised earnings while maintaining benefit levels, is known as an income disregard policy. Additionally, for the first 4 months of employment, AFDC recipients could also disregard an additional $\$ 30$ plus one-third of the remaining earnings. For the next 8 months, recipients could continue to disregard $\$ 30$. Before PRWORA was enacted, states could obtain waivers from the federal government to amend the income disregard policy, allowing families to keep more earnings while on welfare. Under TANF, states have complete leeway to develop their own income disregard programs (USDHHS [U.S. Department of Health and Human Services] 1997). Policies that increase income disregards act as an earnings supplement by allowing parents to combine earnings with income from welfare. Income disregard increases may indirectly affect family arrangements, as they are likely to increase employment and welfare use. They may have ambiguous effects on total income because total work hours may decrease as earnings increase (Peters et al. 2003; Grogger and Karoly 2005).

\section{Paternity Establishment Policies}

Throughout the 1990s states varied in the aggressiveness and effectiveness with which they pursued efforts to establish paternity for children born out of wedlock. Establishment of paternity, policy makers reasoned, would enable the state to recoup the cost of welfare by collecting child support from the fathers of children receiving welfare. The PRWORA mandates that each state move toward establishing paternity for 90 percent of all nonmarital births (Zaslow et al. 1998). There is nevertheless wide variation across states in the rates of achieving this goal. Although paternity establishment increases child support payments and, thus, children's household income (Argys, Peters, and Waldman 2001), the total effect of such policies on living arrangements is unclear, as increased child support enforcement can have offsetting effects on men and women. For example, increases in child support can decrease the costs of nonmarital childbearing for women but increase them for men (Peters et al. 2003). In addition, paternity establishment policies may increase marriage or cohabitation, as such policies also increase the father's costs of maintaining a separate household and paying child 
support. Some research finds that child support and paternity establishment policies are associated with declines in rates of nonmarital childbearing (Garfinkel et al. 1998; Plotnick et al. 2001; Peters et al. 2004) and divorce (Nixon 1997).

Policies for Married Welfare Recipients

Under AFDC, married couples' eligibility for cash assistance was severely limited. The 100-hour rule stated that if the primary wage earner worked more than 100 hours in a month, the family was not eligible for welfare benefits, regardless of income. Additionally, the labor-force attachment rule required that, for the family to qualify for benefits, this earner must either earn at least $\$ 50$ in 6 of the 13 quarters prior to applying for assistance or have been eligible for unemployment compensation in the past year (USDHHS 1997). These strict policies essentially excluded most two-parent families from eligibility for welfare. During the early 1990 s, some states received waivers to change these requirements, allowing some married-couple families to receive public assistance. Under TANF, states can determine their own eligibility standards for married parents. If changes increase the flexibility of eligibility policies for married parents, welfare use is likely to grow among low-income married parents. Such changes also would likely increase marriage among lowincome couples with a previous nonmarital birth and would reduce rates of divorce among married low-income couples (Peters et al. 2003). Robert Moffitt (1998) finds some evidence that, under AFDC, state increases in eligibility for married parents also are related to increases in marriage rates.

\section{Family Caps}

Welfare payments typically increase with family size. This led some to worry that women would have additional children in order to increase their welfare benefits (Murray 1984). During the early 1990s, some states attempted to remove this incentive by imposing limits, called family caps, on the benefits paid to families. Such policies effectively cap the welfare benefit to families, regardless of the family's size. Under TANF, states are free to decide whether and what type of family cap to impose (USDHHS 1997). Family caps are expected to decrease the likelihood that women on public assistance will have additional children (Peters et al. 2003). Nevertheless, research is mixed on the relation between family caps and nonmarital fertility. Several studies find no association between the family cap policy and nonmarital births (Dyer and Fairlie 2004; Joyce et al. 2004; Ryan, Manlove, and Hofferth 2006). Others (Horvath-Rose and Peters 2001; Horvath-Rose, Peters, and Sabia 2008) find evidence that the family cap is associated with a decline in nonmarital births. 


\section{Previous Research on Welfare Reform and Living Arrangements}

Several researchers examine the influence of welfare policies on living arrangements. A large literature, summarized in Moffitt (1998), looks not at specific welfare policies but instead at welfare benefit levels, relating these levels to marriage and fertility behaviors. Moffitt concludes that, in the bare majority of studies, rates of marriage decline and fertility increases as benefits grow. However, the pattern only holds true among white women, and the estimated effects of benefit levels are very small.

Other research examines how specific welfare policies, such as the waivers implemented in the early 1990s, influence living arrangements. The overall evidence is mixed, and several studies find no effect. Other studies indicate that any observed effects depend on a variety of factors such as the specific type of policy examined, the race of the child, the characteristics of the child's family, and the type of living arrangement measured.

Some evidence on the links between welfare policies and living arrangements comes from experimental studies that took place prior to 1996. In their summary of these pre-PRWORA experiments, Jeffrey Grogger and Lynn Karoly (2005) conclude that mandatory work requirements alone do not appear to affect rates of marriage; however, work incentives (such as increases in income disregards) are found to promote marriage by reducing divorce and separation among those who are already married. An evaluation of the Minnesota Family Investment Program, an experimental intervention that required work and helped to increase income, finds that the program led to an increase in marriage (Gennetian and Miller 2004). Another study, which includes data from 14 random assignment studies designed to promote work and reduce welfare, shows that welfare experiments do not increase marriage among single mothers (Gennetian and Knox 2003). Contradictory results are found in analyses of data from welfare reform experiments that increased the income disregard in two sites in Canada (Harknett and Gennetian 2003). In one location, the increased income disregard is associated with an increase in the rate of marriage, but it is associated with a marriage rate decline in the other location. The authors conclude that the effects of welfare policies may be moderated by the local labor market and other conditions.

Other data come from the New Hope project, an experimental study of an antipoverty program that took place in Milwaukee in the mid1990s. Using data from this project, Anna Gassman-Pines, Hirokazu Yoshikawa, and Sandra Nay (2006) find that participation in New Hope leads to an increase in marriage among single mothers. Using both qualitative and quantitative data, the authors further reveal that this increase is primarily due to increased earnings and subsequent im- 
provements in relationship quality among those participating in the program.

Additional studies use nonexperimental data to relate changes in welfare policies to changes in living arrangements. In order to address the fact that states differ from each other in a variety of ways other than in their welfare policies, most nonexperimental studies of this topic include state and year fixed effects. They thereby estimate the influence of welfare reform from within-state policy changes over time. As Grogger and Karoly (2005) note, the results of these studies are inconsistent. Suzanne Ryan and colleagues (2006) use Panel Study of Income Dynamics data (1989-96) to examine the ways in which specific pre-TANF waivers, such as family caps, sanctions, and time limits, influence nonmarital childbearing among unmarried mothers who received welfare. They find no associations between these policies and fertility outcomes.

Gregory Acs and Sandi Nelson (2004) use data from the 1997 and 1999 rounds of the National Survey of America's Families to examine how changes in welfare policies influence children's living arrangements. They focus specifically on the strictness of state sanction policies, whether the states have a family cap, the effectiveness of the state child support enforcement, and whether the state has expanded welfare eligibility for two-parent families. Separate regression analyses are used for each policy, making it difficult to determine whether the results are picking up the effect of one policy or whether a single policy is acting as a proxy for a group of others. Results from these analyses suggest that increases in child support collection and family caps are both associated with a reduction in the number of children living in singleparent families and an increase in the rate of marriage. In contrast, no consistent associations are found for sanction policies or eligibility for married parents. Acs and Nelson (2004) examine whether children lived with a married parent, a single parent, or no parent, but they do not consider whether a single mother doubles up by living with other adults.

John Fitzgerald and David Ribar (2004b) use data from the 1990, 1992, 1993, and 1996 SIPP panels to relate changes in both welfare policies and local economic conditions to the incidence of female headship (i.e., being unmarried and living with a child) and to women's transitions into and out of headship. They focus solely on whether a woman was married and do not examine whether the female head lived in the household with other adults (such as a cohabiting partner or her parents). Their overall results show few statistically significant associations between state welfare policies and female headship. Fitzgerald and Ribar (2004a) use the same data to estimate spells of female headship and welfare participation, finding that participation in welfare increases the amount of time women remain single mothers. Welfare waivers and the implementation of TANF are not found to be associated with spells of welfare participation or of female headship. Like the current work, 
these studies capture a wide range of pre-TANF state welfare policies. Unlike the current article, however, they do not distinguish different types of state TANF policies but instead use a dummy variable to indicate that a state implemented TANF.

Using Current Population Survey (CPS) data for the 1989-2000 period, Marianne Bitler, Jonah Gelbach, and Hilary Hoynes (2006) relate changes in state welfare policies to children's living arrangements. They employ repeated cross-sections of data along with state and year fixed effects. Rather than distinguishing between different types of waiver and TANF policies, the study by Bitler and colleagues (2006) uses dummy variables in the main analysis to indicate whether a state has any waiver or has TANF in place. They find in general that welfare waivers are associated with an increase in the likelihood of living with neither parent (found primarily for African American and white children), a decrease in living with an unmarried parent, and an increase in the likelihood of living with a married parent (concentrated among Hispanics).

Marcia Carlson and colleagues (2004) take the study of the association between welfare policies and living arrangements further, examining welfare policies' links to cohabitation, marriage, and romantic but noncohabiting relationships. Using a sample of couples who recently had a nonmarital birth, the authors relate welfare benefits to a measure of the couples' relationship status 1 year after the birth. They find that high welfare benefits are associated with a decrease in couples' breakups.

To date, most studies of the effect of PRWORA on children's living arrangements include only a simple measure of whether the state implemented TANF. Few measure different welfare policy components such as the implementation of family caps or income disregards. In an era when states have choices about the welfare policies they implement, it is crucial to understand how specific state policies influence children. In addition, because most studies compare state policy changes that occur over time, they run into well-documented estimation problems (National Research Council 2001) when using a single dummy variable for TANF implementation, in that states implemented TANF over a period of a year and a half. To address such issues, this study draws upon data from both before and after TANF implementation to examine the ways in which children's living arrangements are influenced by such specific welfare policy components as time limits, sanctions, and income disregards.

This study also differs from previous work in other ways. In order to provide detailed information about changes in children's living arrangements, it uses multinomial logistic regression models (most other studies employ logistic regression models) to show the specific types of changes that children experience in living arrangements. Logistic regression models reveal whether a change in state policy is associated with an increase in a particular living arrangement (e.g., living with a single 
parent). Multinomial logistic regressions allow one to determine whether an increase in single parenthood resulted from a reduction in marriage or from a reduction in living with other adults, two very different paths into single parenthood. This provides a richer picture of the ways in which welfare policies may influence living arrangements.

In addition to the state fixed-effects models (which have commonly been used in this literature), this study employs the longitudinal design of the SIPP panels to estimate individual fixed-effects models in which changes in living arrangements are tracked for the same child over time. Although state fixed-effects models control for time-invariant characteristics of the state, individual fixed-effects models control for all timeinvariant characteristics of the individual child. Results are contrasted across the two types of models.

\section{Data}

This study examines the influence of state welfare policies on three measures of children's living arrangements: living with a single parent, living with a married parent, and living with a parent and another adult (doubling up). It relies on data from the 1992, 1993, and 1996 panels of the SIPP. The SIPP was designed to help the government evaluate social programs, and SIPP data include detailed information on income, program participation, and family demographics (Westat and Mathematica 2001). A nationally representative sample of households was selected to participate in each panel. The survey provides information about both the household and the individuals within the household. Data were collected every 4 months for the duration of the panel. ${ }^{2}$

In the SIPP, questions about living arrangements are posed at each wave (i.e., every 4 months). These questions identify the parent of each child, the parent's marital status, and the number of other adults in the household. Because the policy variables included in the current study are measured each year, annual measures of children's living arrangements (described in more detail below) were created. A child-year file was created from these data. It includes one observation for each child in each year. Thus, the file includes multiple children from a family and up to four observations per child. All analyses cluster by individual to adjust for the fact that children appear in the data multiple times; this also adjusts for clustering at the state level.

Because the main models (described below) use within-state changes in policies to predict changes in children's living arrangements, the current analyses require an adequate number of children in each state, in each year, and in each of the three living arrangement categories to generate robust estimates. (Grogger and Karoly [2005] discuss the importance of having adequate sample sizes in state-level analyses.) To achieve this, all analyses are restricted to the largest states. These include 
Welfare and Children

Table 1

Distribution of Observations across States and Years

\begin{tabular}{lrrrrrrrrr}
\hline State & 1992 & 1993 & 1994 & 1995 & 1996 & 1997 & 1998 & 1999 & Total \\
\hline Alabama & 145 & 223 & 206 & 74 & 221 & 201 & 178 & 166 & 1,414 \\
California & 444 & 814 & 710 & 354 & 632 & 497 & 422 & 379 & 4,252 \\
Florida & 268 & 504 & 461 & 218 & 454 & 333 & 275 & 238 & 2,751 \\
Georgia & 221 & 470 & 434 & 215 & 405 & 320 & 281 & 243 & 2,589 \\
Illinois & 278 & 537 & 529 & 255 & 369 & 345 & 272 & 232 & 2,817 \\
Indiana & 167 & 398 & 387 & 205 & 255 & 244 & 224 & 198 & 2,078 \\
Maryland & 106 & 203 & 181 & 75 & 159 & 142 & 109 & 84 & 1,059 \\
Michigan & 279 & 538 & 502 & 223 & 398 & 352 & 273 & 262 & 2,827 \\
Mississippi & 131 & 252 & 228 & 92 & 229 & 202 & 207 & 176 & 1,517 \\
Missouri & 180 & 332 & 311 & 151 & 282 & 250 & 204 & 171 & 1,881 \\
New Jersey & 163 & 337 & 315 & 158 & 260 & 223 & 326 & 153 & 1,790 \\
New York & 389 & 730 & 641 & 309 & 567 & 469 & 409 & 361 & 3,875 \\
North Carolina & 219 & 386 & 363 & 151 & 314 & 306 & 244 & 196 & 2,179 \\
Ohio & 299 & 560 & 531 & 259 & 494 & 396 & 326 & 314 & 3,179 \\
Pennsylvania & 332 & 639 & 609 & 281 & 539 & 513 & 420 & 367 & 3,700 \\
South Carolina & 106 & 227 & 220 & 118 & 251 & 202 & 165 & 150 & 1,439 \\
Tennessee & 134 & 264 & 236 & 119 & 267 & 237 & 192 & 164 & 1,613 \\
Texas & 323 & 618 & 556 & 257 & 493 & 452 & 368 & 326 & 3,393 \\
Virginia & 124 & 256 & 231 & 112 & 232 & 195 & 185 & 159 & 1,494 \\
$\quad$ Total & 4,308 & 8,288 & 7,651 & 3,626 & 6,821 & 5,879 & 4,935 & 4,339 & 45,847 \\
& & & & & & & & & \\
\hline
\end{tabular}

SourcEs. - 1992, 1993, and 1996 panels of the Survey of Income and Program Participation.

NoTE. - Sample restricted to non-Hispanic African American children and children of low-educated (high school degree or less) non-Hispanic whites who live in the states listed.

states that have at least five observations in each category of living arrangements (married, single, and doubled up) in every year for both the white and African American subsamples. Nineteen states meet these criteria, providing data that represent 73 percent of the child-spell observations in the SIPP panels (see table 1 for a list of included states).

The prevalence of various living arrangements varies greatly by race. Analyses are therefore conducted separately for non-Hispanic white children and for non-Hispanic African American children. Because of inadequate sample sizes, it is not possible to separately examine Hispanics. Specifically, 68 percent of the person-year observations of Hispanics are clustered in only two states, and 82 percent are clustered in four states. As a result, any state-level analyses using Hispanic children would be limited to a very small number of states and would not be comparable to the other analyses.

Analyses exclude spells in which children live in households without either biological parent. In addition, because welfare policies may be particularly influential on the living arrangements of children in families that are most likely to use welfare, the sample of white children is restricted to those whose mother (or household head, if information on the mother is missing) has no more than a high school degree 
(diploma or general equivalency diploma; $n=29,713$ child-year observations). For African American children, sample sizes are not sufficient to apply this education restriction. ${ }^{3}$ The analyses for African American children therefore include those with all levels of parental education ( $n=16,134$ child-year observations). Even without the education restriction, however, the African American sample includes more households that receive welfare income (35 percent) than does the white sample (12 percent). The difference is due in part to the high number of African American children in single-parent families. To account for this difference between the white and African American samples, analyses using data for the African American sample include a dummy variable that indicates whether the child's parent has more than a high school degree. As noted below, some sensitivity tests examine how the pattern of results for the less educated white sample compares with the pattern for those who have a high school degree or more. Finally, to avoid including children who are themselves parents, the sample is limited to children who are aged 15 or younger.

\section{Methods}

The goal of these analyses is to relate changes in state welfare policies throughout the 1990s to changes in children's living arrangements. The statistical models predict whether a child lives with a married parent, with a single parent, or in a doubled-up household. Several different specifications are estimated in order to identify effects that are robust across models. Because the current analyses are based on a unique sample of children in 19 select states, and because they involve statelevel analyses, weights are not used.

The state fixed-effects analyses employ a repeated cross-section model that identifies policy effects from differences in state policies. Multinomial logistic regression models are used as the primary specification and are characterized as follows:

$$
\operatorname{Pr}\left(y_{i}=j\right)=\frac{\left[\exp \left(\mathbf{X}_{i s t} \beta_{1 j}+\beta_{2 j} \mathbf{W}_{s t}+\beta_{3 j} \mathbf{C}_{s t}+\kappa_{j s} \mathbf{S}_{s}+\delta_{j} \mathbf{d}_{t}+\varepsilon_{i s t}\right)\right]}{\left[1+\sum_{j}^{J} \exp \left(\mathbf{X}_{i s t} \beta_{1 j}+\beta_{2 j} \mathbf{W}_{s t}+\beta_{3 j} \mathbf{C}_{s t}+\kappa_{j s} \mathbf{S}_{s}+\delta_{j} \mathbf{d}_{t}+\varepsilon_{i s t}\right)\right]},
$$

where $j$ indicates the number of categories of living arrangements examined; $i, s$, and $t$ index the individual, state, and year, respectively; $\mathbf{X}$ is a set of exogenous child and family characteristics; $\mathbf{W}$ is a vector of state welfare policy variables; $\mathbf{C}$ is a set of controls for state economic conditions; $\mathbf{S}$ is a set of state dummies; and $\mathbf{d}$ is a set of year dummies. These models estimate whether within-state changes in welfare policies are associated with changes in children's living arrangements. The base category is varied in order to examine three sets of arrangements: the likelihood of living with a married parent is compared to that of living 
with a single parent, the likelihood of living with a married parent is compared to that of living in a doubled-up household, and the likelihood of living with a single parent is compared to that of living in a doubled-up household. To facilitate comparisons between the state and child fixed-effects models, results from logistic regression models with state fixed effects are also presented.

Results from child-specific fixed-effects analyses are also presented. These analyses examine whether changes in state welfare policies are related to within-child changes in living arrangements over time. This model controls for any child or family characteristics that do not change over time and adjusts for the fact that unobserved characteristics of a child and his or her family may be associated both with that child's living arrangements and with the state in which the family lives. Because the child fixed-effects model cannot be estimated for children who do not experience a transition in living arrangements during the panel, the sample size for these analyses is substantially smaller than that used in the state fixed-effects model. Because of the small sample size, adequate power is not available to perform multinomial logistic regression models; therefore, results are presented from logistic regression models that are characterized as follows:

$$
\operatorname{Pr}\left(y_{i}=1\right)=1 /\left\{1+\exp \left[-\left(\beta_{1 j} \mathbf{X}_{i s t}+\beta_{2 j} \mathbf{W}_{s t}+\beta_{3 j} \mathbf{C}_{s t}+\kappa_{j i} \mathbf{I}_{i}+\varepsilon_{i s t}\right)\right]\right\},
$$

where all variables are as above. However, the state and time fixed effects are removed, and an individual fixed effect $\left(\mathbf{I}_{i}\right)$ is included, instead.

Each model (state and child fixed effects) has strengths and limitations. The advantage of state fixed-effects models lies in the larger sample size, which allows analyses to use data on all children and to estimate multinomial logistic regressions. These regressions provide rich comparisons of various living arrangements. The child fixed-effects model, although based on a much smaller sample of children, is estimated from data on children who are actually observed making a transition in living arrangements over the same time period that a welfare policy change was enacted. This model also enables one to control for any unobservable, time-invariant characteristics of the child or his or her family.

As Hoynes (1997) notes, results from state and individual fixed-effects models should differ only if people move between states in ways that are correlated with welfare policies. Only 1.37 percent of the children in the sample are observed moving between the states included in the analyses during the panel. Given the large sample sizes, this is not likely to be enough movement to influence results. Accordingly, the child and state fixed-effects models should produce similar results. However, because the SIPP is a panel data set that follows households, not a longitudinal study of children, children enter and leave the sample for many reasons (e.g., birth, moving to or from a nonincluded state, moving into or out of a sampled household, reaching age 16, and panel 
attrition). ${ }^{4}$ Of the 18,913 children ever in the analysis sample, only 46 percent contribute observations for the potential maximum of 3 years (in the 1992 and 1993 panels) or 4 years (in the 1996 panel). These movements into and out of the panel may increase the standard errors on the estimates but should only bias the coefficients if systematically associated with welfare policies; for instance, such bias might occur if the policies consistently cause people to move across state lines or out of the sample. Given the strengths and weaknesses of these various models, the discussion focuses on results that are robust across model specifications.

\section{Measures}

\section{Dependent Variables}

The three main dependent variables are dummy variables measuring children's living arrangements. The first dummy variable, Married, indicates that a child lives with a married parent (including biological married parents as well as married stepmother and stepfather families). A second dummy variable, Doubled Up, indicates that a child lives with a single parent (either the mother or father) and with other adults (including cohabitors, grandparents, roommates, and children over age 18). ${ }^{5}$ A third dummy variable, Single, indicates that a child lives with an unmarried parent (either the mother or father) and no other adults.

The measures of living arrangements are based on snapshots taken at the first interview and again every 12 months thereafter. These snapshots provide a measure of living arrangements for each year that the children are in the panel. Thus, the measure of living arrangements in 1996 refers to the spring of that year (when the first wave of data was collected), the 1997 measure indicates the living arrangement 12 months later, and so on. Changes occurring in the intervening 12 months are reflected in the next year's measure of living arrangements. This means that it is possible to miss some short-term living arrangements if they start and end within a year. In addition, it is possible that the policy changes measured here were enacted after the measure of living arrangements was taken in a given year. This is one reason why the preferred analyses relate policy changes enacted in a prior year to changes in living arrangements in the subsequent year (described below). Although data on monthly living arrangements are available in the SIPP, annual measures are used here. It seems implausible that policy changes could affect living arrangements so rapidly as to make a monthly assessment useful. Table 2 shows the distribution of observations across living arrangements for the white and African American samples used in the analyses. 
Welfare and Children

Table 2

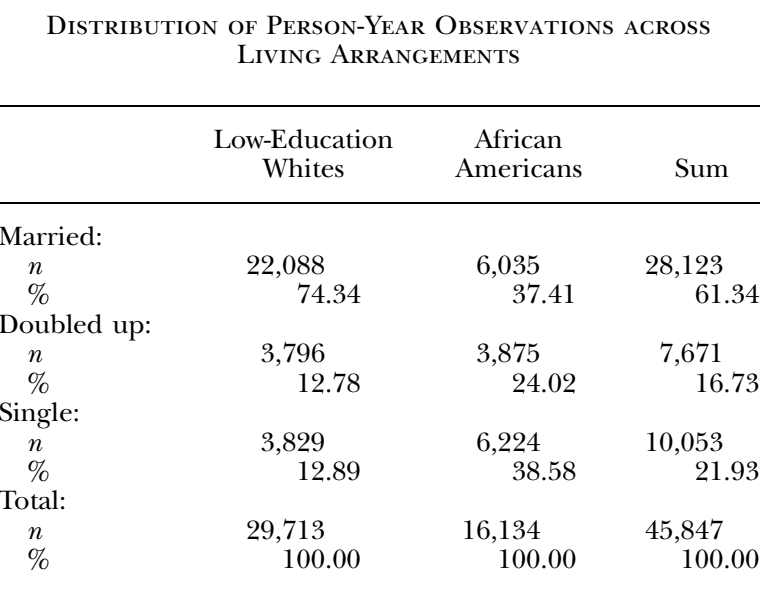

Sources. - 1992, 1993, and 1996 panel of the Survey of Income and Program Participation.

NoTE.-Sample restricted to non-Hispanic African American children and children of low-educated (high school degree or less) non-Hispanic whites who live in large states. Results are not weighted.

Control Variables from the SIPP

Analyses include a small set of individual and family control variables that are available in all three panels of the SIPP on an annual basis and that are not themselves influenced by state welfare policies: child's age (ranging from 0 to 15 years), parent's age (ranging from 18 to 84 years), and child sex $(0=$ female, $1=$ male $) .{ }^{6}$ For the African American sample, parental education is controlled using a dummy that indicates whether the parent had more than a high school degree.

\section{State Welfare Policies}

The welfare policy variables represent choices that states made between 1992 and 1999 in creating their public assistance programs for lowincome families. Researchers have struggled with how to code welfare policies in order to capture the diversity of policies that occurred across the states and over time. Many analyses of welfare reform's relations with living arrangements use simple dummy variables to indicate periods in which states had any pre-TANF waiver in effect and those in which TANF was in effect (e.g., Bitler et al. 2006). Fewer studies disaggregate the specific types of waivers that states had in the pre-TANF period. For example, some distinguish between the effects of an income disregard waiver and those of a family cap waiver (see, e.g., Fitzgerald and Ribar 2004b). Very few studies examine specific dimensions of state policies 
Table 3

Variation in State Policies: 19 Large States

\begin{tabular}{|c|c|c|c|c|c|c|c|c|}
\hline & 1992 & 1993 & 1994 & 1995 & 1996 & 1997 & 1998 & 1999 \\
\hline Any time limit before TANF & 0 & 0 & 1 & 3 & 12 & 16 & 17 & 17 \\
\hline Strict time limit under TANF & 0 & 0 & 0 & 0 & 1 & 2 & 2 & 2 \\
\hline Any sanction before TANF & 1 & 1 & 3 & 6 & 14 & 18 & 19 & 19 \\
\hline Strict sanction under TANF & 0 & 0 & 0 & 0 & 2 & 13 & 13 & 14 \\
\hline Any income disregard before TANF & 2 & 3 & 5 & 7 & 14 & 19 & 19 & 19 \\
\hline Generous ID under TANF & 0 & 0 & 0 & 0 & 1 & 4 & 4 & 3 \\
\hline Family cap & 0 & 1 & 2 & 2 & 6 & 9 & 11 & 11 \\
\hline $\begin{array}{l}\text { Increased eligibility for married } \\
\text { families }\end{array}$ & 3 & 4 & 5 & 8 & 14 & 14 & 12 & 12 \\
\hline
\end{tabular}

NotE. - TANF $=$ Temporary Assistance for Needy Families program; ID $=$ income disregard. For the generous income disregard variable there is more change than apparent between 1997 and 1998 because different states are coded one in the years since implementations of TANF.

since the implementation of TANF (exceptions are Acs and Nelson 2004 and Horvath-Rose et al. 2008). However, as noted earlier, studies run into identification problems in using a single TANF dummy, as all states implemented TANF over a period of a year and a half.

The current study capitalizes on two sources of variation in state welfare policies: variation in the implementation of specific welfare policy waivers in the pre-TANF period and variation in the strictness of state welfare policies in the period since TANF implementation. Methodologically, this strategy provides greater policy variation in the TANF period, thus reducing (though not eliminating) the estimation problems faced by studies that use a dummy variable for TANF implementation. In addition, this strategy provides more specific information about the estimated effects of various state policies on children's living arrangements.

To operationalize this strategy, models include two variables for some key policy measures. For instance, two variables measure states' sanction policies. The first of these variables is an indicator of whether the state imposes any kind of sanction. In the pre-TANF period, this indicator is coded one for each year in which a state had a sanction waiver in place and zero otherwise; in the TANF period (i.e., after TANF was implemented), when sanctions became universal, this variable is coded one for all states. The second sanction variable measures the strictness of a state's sanction policy in the TANF era. It is equal to zero in years before TANF was implemented (1992-95 for most states; 1992-97 for California). After the implementation of TANF, this variable equals one if a state has a comparably strict sanction policy and is zero otherwise. Table 3 shows the number of states that have in place each type of policy in each year. 
The state fixed-effects analyses include state and year dummy variables, which account for unobserved between-state differences that may influence children's living arrangements. Therefore, estimates of the influence of policies on living arrangements are derived from withinstate changes in welfare policies over time. The child fixed-effects analyses are based on changes in individual living arrangements that occur along with within-state changes in welfare policies. One drawback of these strategies is that they place a great deal of demand upon the data; specifically, they are based on the assumption that children's living arrangements will change in the same year that states change welfare policies. To address this, the preferred models include a 1-year lag between the policy change and the measurement of living arrangements. Additionally, if state policies are highly correlated, then it will be difficult to precisely estimate the effect of one policy among many. In order to reduce this possibility, analyses exclude policies that are highly correlated with other represented policies. For instance, many previous studies account for the generosity of states' welfare policies by including a control for the maximum AFDC or TANF benefit level for a family of three. However, this variable is excluded here because it is highly correlated with the measure of the incremental benefit available upon the birth of another child (described below); therefore, a measure of the maximum benefit level is excluded in the analyses.

Time limits. - Time limits are measured with two dummy variables. The first variable is coded one for the year that the state implemented a time limit through a waiver and for each year thereafter. All states are coded one for this variable after the state implemented TANF, as TANF made time limits universal (exceptions are Michigan and New York, which do not have time limits, even under TANF). Data on state implementation of time limit waivers come from Gil Crouse (1999). The second variable captures whether the state has a strict time limit policy in the TANF era. It is scored as one if the state has a time limit of less than 5 years (i.e., more strict than the federal standard) and zero otherwise (Urban Institute n.d.).

Sanctions.-Sanctions are also measured with two dummy variables. First, states are coded one for the year in which the state implemented a sanction (either under a waiver or under TANF) and for each year thereafter (data from Crouse 1999). All states are coded one on this variable after the implementation of TANF made sanctions universal. The second variable captures whether states have a strict sanction policy: states are coded one if they have a full-benefit sanction, rather than a partial one (that is, the benefit for the entire family is eliminated instead of reduced when sanctions are imposed; Urban Institute n.d.) and zero otherwise.

Income disregards. - Two dummy variables capture states' income disregard policies. In the first, states are coded with a variable equaling 
one in the year that they first allowed welfare recipients to keep more of their earnings while remaining eligible for welfare, and are coded thusly for each year thereafter. In the TANF period, a variable for the generosity of the state's income disregard is used. This measure equals one if a state is in the highest quartile for the amount of income that is disregarded (Urban Institute n.d.). Thus, in contrast to the preceding variables, the income disregard measure in both the pre-welfare reform and welfare reform periods indicates states that are more generous than other states.

Paternity establishment.-For each year, a state's effectiveness in establishing paternities is measured with the paternity establishment rate. This is the number of paternities established in a state divided by the number of out-of-wedlock births, for each year (Administration for Children and Families 1994, 1995, 1996, 1997, 1998, 1999, 2000; National Center for Health Statistics n.d.). This rate for a given year can be greater than one if the state establishes paternities both for births in that year and for births from previous years.

Eligibility for married parents. - For each year in the pre-TANF and TANF periods, a dummy variable is created to indicate whether a state relaxed the restrictive eligibility rules for married-parent families. This variable is coded one if a state eliminated the 100-hour rule or the labor-force attachment rule and zero if neither rule was eliminated. Data for this measure came from USDHHS (1997).

Family caps.-As noted earlier, some states were concerned that increasing welfare benefits to cover growth in family size encourages welfare recipients to have additional children. In order to change this incentive, some states adopted policies that limit (or eliminate) the amount of additional benefits provided to mothers who bear children while they receive welfare benefits. However, when states compute food stamp benefits, cash assistance is taxed at a 30 percent rate. This means that, among families of the same size, those that have their benefits capped are actually eligible for more food stamp assistance than those that have not. Finally, some states that have family caps provide families with a voucher to be used for approved purchases (e.g., Wallace 2009). To capture all this variation in family cap policies, this study uses a variable representing the total incremental cash assistance and food stamp benefit (in constant 1999 dollars) that a family would receive if a single mother with two children in that state gave birth to another child (Geoffrey Wallace, personal communication). This allows one not only to distinguish states with caps from states that lack them but also to address the nuanced ways in which states' family cap policies differ. Moreover, this allows analyses to assess the actual impact that living in a capped state would have on a family's resources. Because the existence of a family cap policy may have an effect independent of the actual cash 
benefits, we also include a dummy variable coded as one if the state has a family cap in place in a given year.

The measures used in this study describe the actual policies implemented by states as a result of welfare reform. As noted above, the focus is on the main policy areas in which welfare reform took place, because these areas are most likely to play a role in children's living arrangements. Other research uses a much wider set of state policies and performs factor analysis to identify policy typologies that were implemented in the wake of welfare reform (Graefe, De Jong, and Irving 2006; De Jong et al. 2006). Such research helps categorize patterns of welfare policies, describing how such patterns changed over time and vary across states. However, it does not inform policy makers about whether specific welfare policies, if implemented, are likely to produce changes in living arrangements. Both strategies provide useful information; this study focuses on individual policies because the goal is to understand the effects of specific policies.

\section{State Control Measures}

Analyses also control for other state-level factors that might influence state decisions to implement the examined welfare policies and the measured outcomes. Analyses control for these factors in each year. The preferred models lag each of these controls by 1 year. The controls include the unemployment rate for men and women (Bureau of Labor Statistics n.d.), real median wages for men and women (authors' calculations using 3-year moving averages from March CPS data), the maximum value of the federal and state earned income tax credit (EITC) for a single mother with two children in constant 1999 dollars (Leigh 2003; Tax Policy Center 2009), the amount of federal housing money spent per 1,000 residents in the state (U.S. Census Bureau 1993-2001), the income eligibility limit for Medicaid for pregnant women (National Governors Association 2001), and the annual employment growth rate (data from the Bureau of Labor Statistics, Local Area Unemployment Statistics). It is important to note that this study may still not be able to measure all of the important within-state changes that are associated with changes in family structure.

Tables 4 and 5 present descriptive statistics for all independent variables used in the analyses. Results are listed separately by race.

\section{Specification Tests}

As described above, the preferred specification uses dummy variables to indicate a year in which a specific policy was implemented and lags the policies by 1 year. This coding system uses dummy variables to indicate whether a given policy was in place in a given year. For most of 
Table 4

Descriptive Statistics for Children of Women with High School Degree OR LESS $(N=29,713)$

\begin{tabular}{|c|c|c|c|c|}
\hline & Mean & SD & Min & $\operatorname{Max}$ \\
\hline Any time limit before TANF & .36 & $\ldots$ & 0 & 1 \\
\hline Strict time limit under TANF & .04 & $\ldots$ & 0 & 1 \\
\hline Any sanction before TANF & .46 & $\cdots$ & 0 & 1 \\
\hline Strict sanction under TANF & .21 & $\ldots$ & 0 & 1 \\
\hline Any ID before-TANF & .56 & $\cdots$ & 0 & 1 \\
\hline Generous ID under TANF & .07 & $\ldots$ & 0 & 1 \\
\hline Paternity establishment rate & .59 & .36 & .04 & 2.52 \\
\hline Increased eligibility for married families & .45 & $\ldots$ & 0 & 1 \\
\hline Family cap & .21 & $\begin{array}{l}\cdots \\
\cdots\end{array}$ & 0 & 1 \\
\hline State EITC $(\$ 100 \mathrm{~s})$ & 32.65 & 10.01 & 17.72 & 49.58 \\
\hline Housing $(\$ 100 \mathrm{~s})$ & .38 & $\ldots$ & 0 & 1 \\
\hline Incremental benefits $(\$ 100 \mathrm{~s})$ & 1.15 & .24 & .71 & 1.67 \\
\hline Unemployment rate $(\%)$ & 5.82 & 1.44 & 2.78 & 9.38 \\
\hline Median real wage (hourly $\$$ ) & 13.01 & 1.43 & 9.90 & 17.07 \\
\hline Medicaid eligibility limit (\% of poverty line) & 175.75 & 38.55 & 133 & 400 \\
\hline Employment growth & .02 & .01 & -.02 & .04 \\
\hline Child is male & .52 & $\ldots$ & 0 & 1 \\
\hline Child's age (years) & 7.73 & 4.49 & 0 & 15 \\
\hline Parent's age (years) & 33.44 & 6.85 & 18 & 84 \\
\hline
\end{tabular}

SourCES. - 1992, 1993, and 1996 panels of the Survey of Income and Program Participation. Note. -SD = standard deviation; TANF = Temporary Assistance for Needy Families program; EITC = Earned Income Tax Credit; ID = income disregard policy. Sample is restricted to those who live in 19 large states. Results are for all person-year spells included in multivariate analyses and are not weighted.

these policies, this system is used because the real variation comes from whether a state has a policy in place or not, and there is very little variation otherwise. For example, there is very little variation among states with a time limit in place; such states either have a 2- or 5-year limit. The only measure that could potentially be used in a continuous manner is the measure of a state's income disregard, which ranges from $\$ 0$ to over $\$ 900$. Additional analyses examine whether results are robust to the use of a continuous measure of income disregard (available upon request). These analyses do not appreciably change the main results.

Several other specification tests were also conducted in order to ensure that the results are robust to alternate policy specifications. Some tests code policy variables according to the proportion of the year the state had a specific policy in place (instead of using a dummy variable indicating that the state implemented the policy at any point in the year). ${ }^{7}$ Both the dummy variable and the proportion specifications were also tested with the welfare policies and state control variables that are not lagged by 1 year. Other analyses use the full sample of states instead of the large-state restriction discussed above. The results presented below stem from the preferred specification, which uses dummy variables to indicate a year in which a specific policy was implemented and lags 
Welfare and Children

Table 5

Descriptive Statistics for African American Women $(N=16,134)$

\begin{tabular}{|c|c|c|c|c|}
\hline & Mean & $\mathrm{SD}$ & Min & Max \\
\hline Any time limit pre-TANF & .41 & $\ldots$ & 0 & 1 \\
\hline Strict time limit under TANF & .07 & $\ldots$ & 0 & 1 \\
\hline Any sanction pre-TANF & .53 & $\ldots$ & 0 & 1 \\
\hline Strict sanction under TANF & .27 & $\ldots$ & 0 & 1 \\
\hline Any ID pre-TANF & .60 & $\ldots$ & 0 & 1 \\
\hline Generous ID under TANF & .08 & $\ldots$ & 0 & 1 \\
\hline Paternity establishment rate & .57 & .33 & .04 & 2.52 \\
\hline Increased eligibility for married families & .48 & $\ldots$ & 0 & 1 \\
\hline Family cap & .27 & $\ldots$ & 0 & 1 \\
\hline State EITC $(\$ 100$ s $)$ & 34.04 & 9.98 & 17.72 & 49.58 \\
\hline Housing $(\$ 100 \mathrm{~s})$ & .40 & $\ldots$ & 0 & 1 \\
\hline Incremental benefits $(\$ 100$ s) & 1.11 & .25 & .71 & 1.67 \\
\hline Unemployment rate $(\%)$ & 5.67 & 1.38 & 2.78 & 9.38 \\
\hline Median real wage (hourly $\$$ ) & 12.81 & 1.48 & 9.90 & 17.07 \\
\hline Medicaid eligibility limit (\% of poverty line) & 176.89 & 31.31 & 133 & 400 \\
\hline Employment growth & .02 & .01 & -.02 & .04 \\
\hline Child is male & .51 & $\ldots$ & 0 & 1 \\
\hline Child's age (years) & 7.56 & 4.47 & 0 & 15 \\
\hline Parent's age (years) & 33.17 & 7.51 & 18 & 71 \\
\hline Parent has more than HS degree & .39 & $\ldots$ & 0 & 1 \\
\hline
\end{tabular}

Sources. - 1992, 1993, and 1996 panels of the Survey of Income and Program Participation.

Note. - SD = standard deviation; TANF = Temporary Assistance for Needy Families program; EITC = Earned Income Tax Credit; ID = income disregard policy; HS = high school. Sample restricted to those who live in 19 large states. Results are for all personyear spells included in multivariate analyses and are not weighted.

this dummy variable by 1 year. A summary table also presents results from alternate model specifications. The discussion is restricted to results that are robust across model specifications.

\section{Results}

Table 6 presents results from multinomial logistic regression analyses that use the state fixed-effects models shown in equation (1). For each group of children, three columns of logit coefficients are presented to highlight the three possible comparisons in the multinomial logit model; these coefficients are computed by changing the omitted category of living arrangements. Results are presented separately for white children of parents with low education (a high school degree or less) and for African American children. Table 7 summarizes state fixed-effects analyses using alternative methods of coding the policy variables. Results marked with an asterisk in table 7 are robust across various policy coding schemes.

Results from table 6 show some scattered associations between welfare policies and children's living arrangements. Most of these are for African 


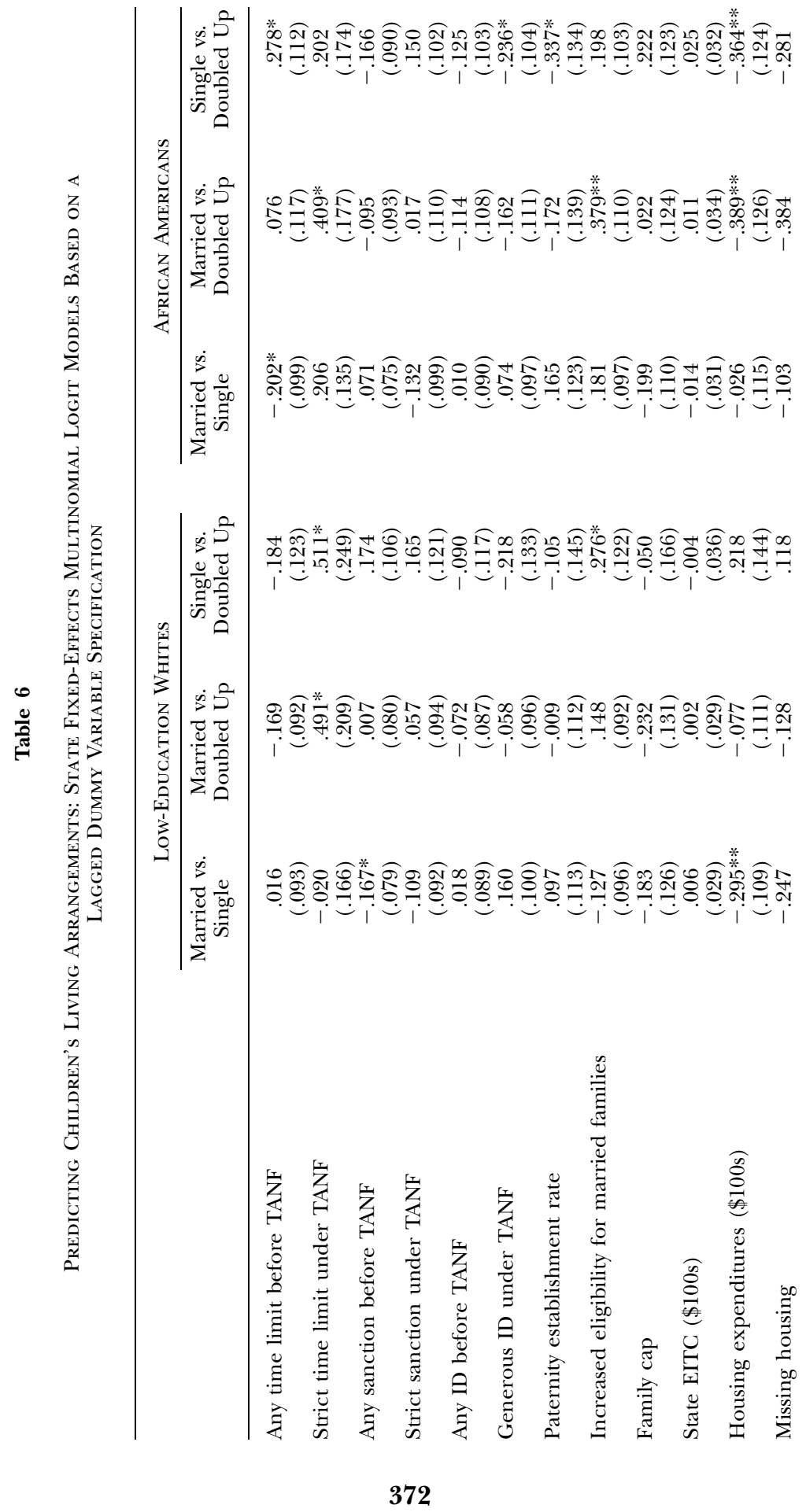




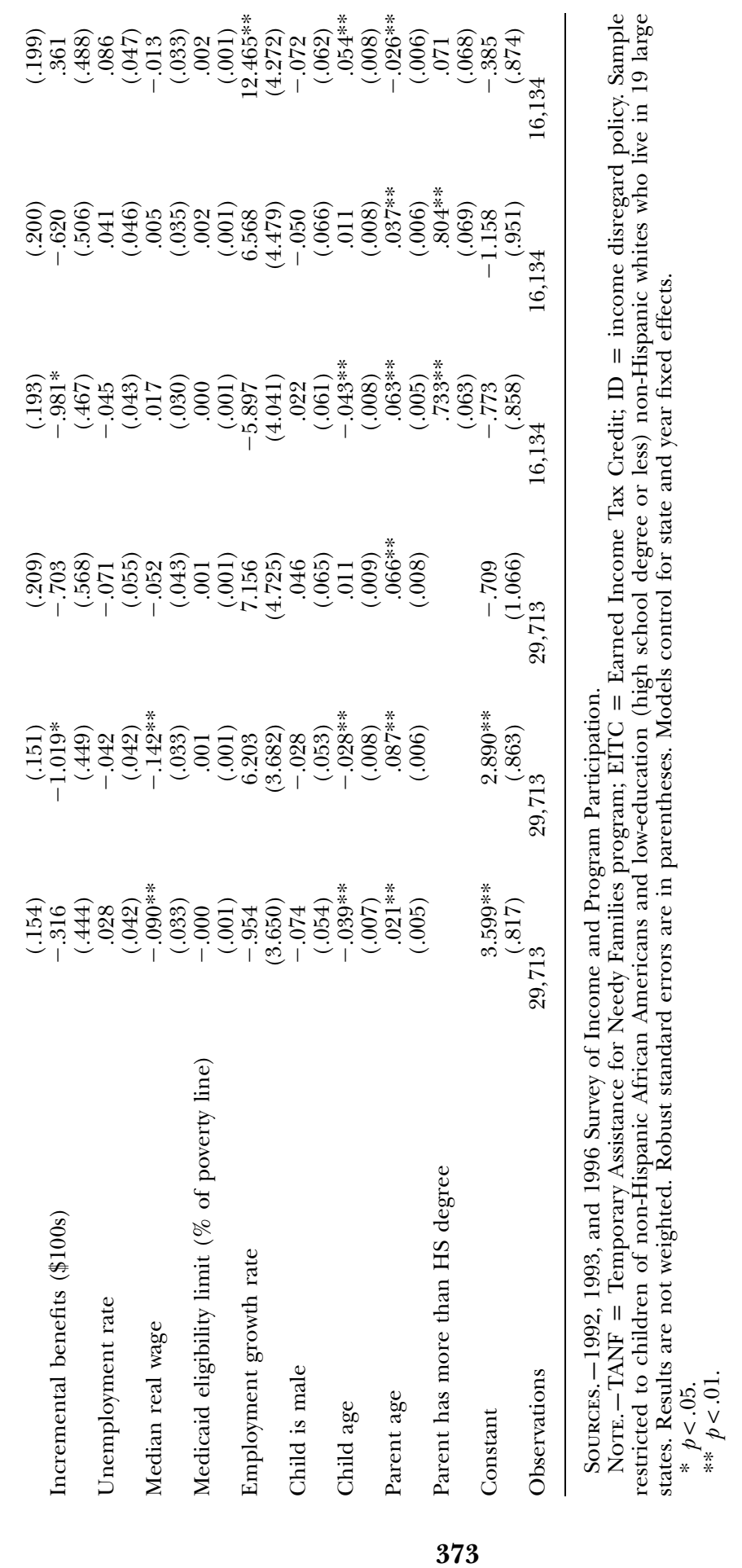




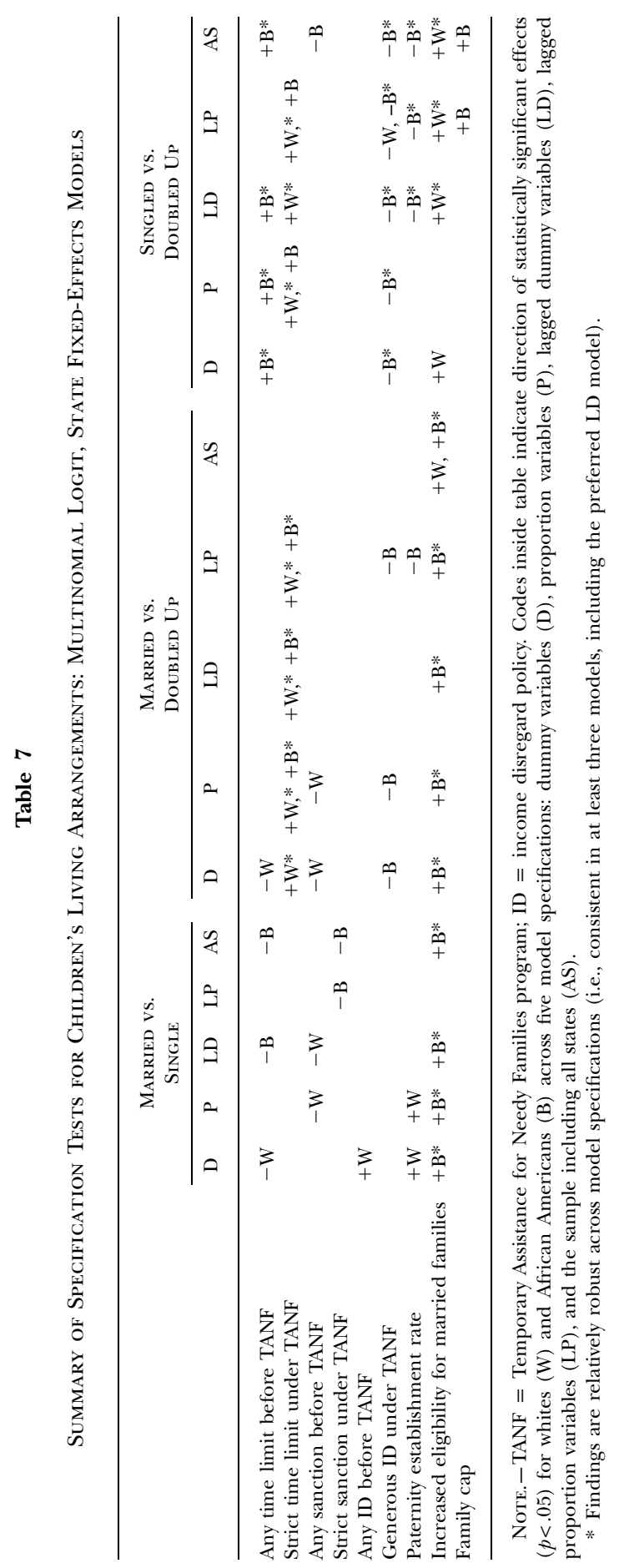


American children. Some associations are not robust across model specifications, but others are consistent across the policy measures (as identified by asterisks in table 7 ). The discussion focuses on relations that are consistent in at least three policy specifications, including the preferred lagged dummy variable specification.

Table 6 provides evidence that time limits in the pre-TANF years are associated with an increase in the likelihood that African American children live with single parents relative to the likelihood that they live in doubled-up households. For African American and for white children in the restricted sample, strict time limits under TANF are associated with an increase in the likelihood of living with married parents relative to that of living in a doubled-up household. For white children, the same policy is also associated with an increase in the likelihood of living with a single mother relative to that of living in a doubled-up household. Additionally, a generous income disregard under TANF is associated with a decrease in the likelihood that African American children live with a single parent relative to the likelihood that they live in a doubledup household. Increases in the rate of paternity establishment are associated with a decrease in the likelihood that African American children live with a single mother relative to that of living in a doubled-up household. Also, for African American children, policies that increase eligibility for married families are associated with an increase in the likelihood of living with a married parent relative to that of living in a doubled-up household. In contrast, for white children in this sample, such policies are associated with an increase in the likelihood of living with a single parent relative to that of living in a doubled-up household. These associations are relatively consistent across various methods of coding policy variables.

One striking feature is the fact that the pattern of results differs a great deal by race; there are very few instances in which the pattern of statistically significant results is the same for both white and African American children. In addition, no policy has the same estimated effect during the pre-TANF period as it has after the implementation of TANF. For example, time limits before TANF are associated with an increase in the likelihood that African American children live with a single parent relative to the likelihood that they live in a doubled-up household; time limits under TANF are associated with an increase in the likelihood that African American children will live in married households relative to that of living with single parents.

As noted above, the sample of white children was restricted to those whose mothers have a high school degree or less. The restriction is based on the assumption that welfare policies would be more likely to influence the living arrangements of these mothers. An additional specification test looks at the sample of white children living with mothers who have more than a high school degree. In principle, there should 
be few or no associations between welfare policies and living arrangements for children in this group. Indeed, this is the case for the most part (results not shown). Of the four statistically significant associations shown in table 6 for white children of low-education parents, none is statistically significant when the test looks at children whose mothers have more than a high school degree. However, two new statistically significant associations do emerge in the specification with the children of more educated mothers. Specifically, the presence of a pre-TANF time limit is associated with a decrease in the likelihood of both marriage and single parenthood. This suggests that the measure of pre-TANF time limits may pick up some other aspect of state policies or environments that influenced the behavior of even more advantaged families, increasing the skepticism over any results concerning this measure.

Table 8 presents a summary of the results of state fixed-effects models based on logistic regressions (in contrast to the multinomial logistic results shown in table 7). These results facilitate comparisons with the individual fixed-effects models that are presented below. In the state fixed-effects models, the comparison group includes more than one living arrangement; for instance, when looking at the likelihood that a child lives in a doubled-up household, the comparison group is children living in both married and single-parent arrangements. Results in table 8 are consistent with those from table 7 .

Table 9 presents the results of the individual fixed-effects models (eq. [2]), which relate changes in state welfare policies to changes in individual children's living arrangements over time. A summary of results from alternative specifications is presented in table 10. Some results are consistent across the various methods of measuring welfare policies. Some of these results are also consistent with the findings in the state fixed-effects models. The presence of pre-TANF time limits is associated with an increase in the likelihood that African American children live with a single parent relative to all other living arrangements. Among white children in this restricted sample, strict time limits under TANF are associated with an increase in the likelihood of living with a single parent. Strict time limits under TANF are also associated with an increase in the likelihood that African American children live in a married household. Finally, a generous income disregard under TANF is associated with a decrease in the likelihood that African American children will live with a single parent.

In some cases, associations that fall short of statistical significance in the state fixed-effects models appear to attain it in the individual fixedeffects models and vice versa. Associations between increased eligibility for married families and the likelihood that African American children live in married families, associations that are statistically significant in tables 7 and 8 , are not statistically significant in the individual fixedeffects models. An association between a family cap and increased like- 


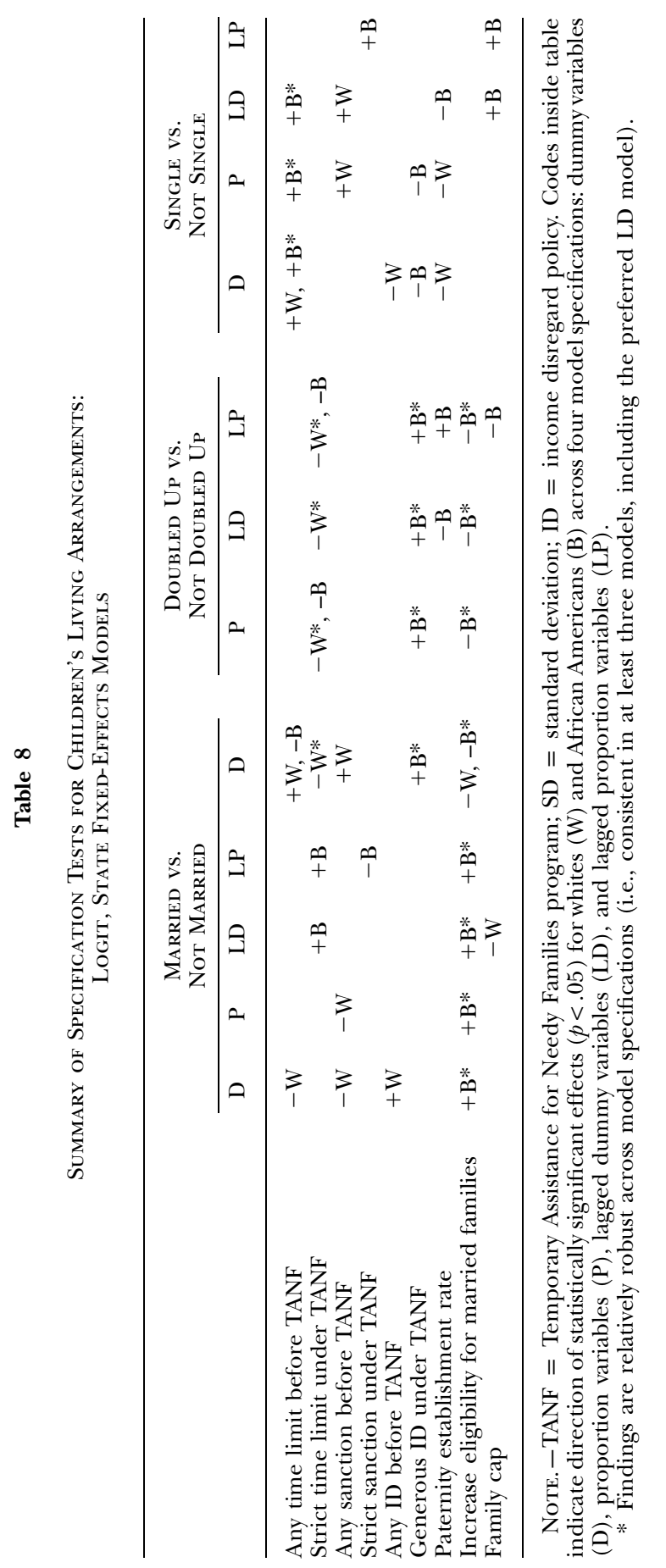




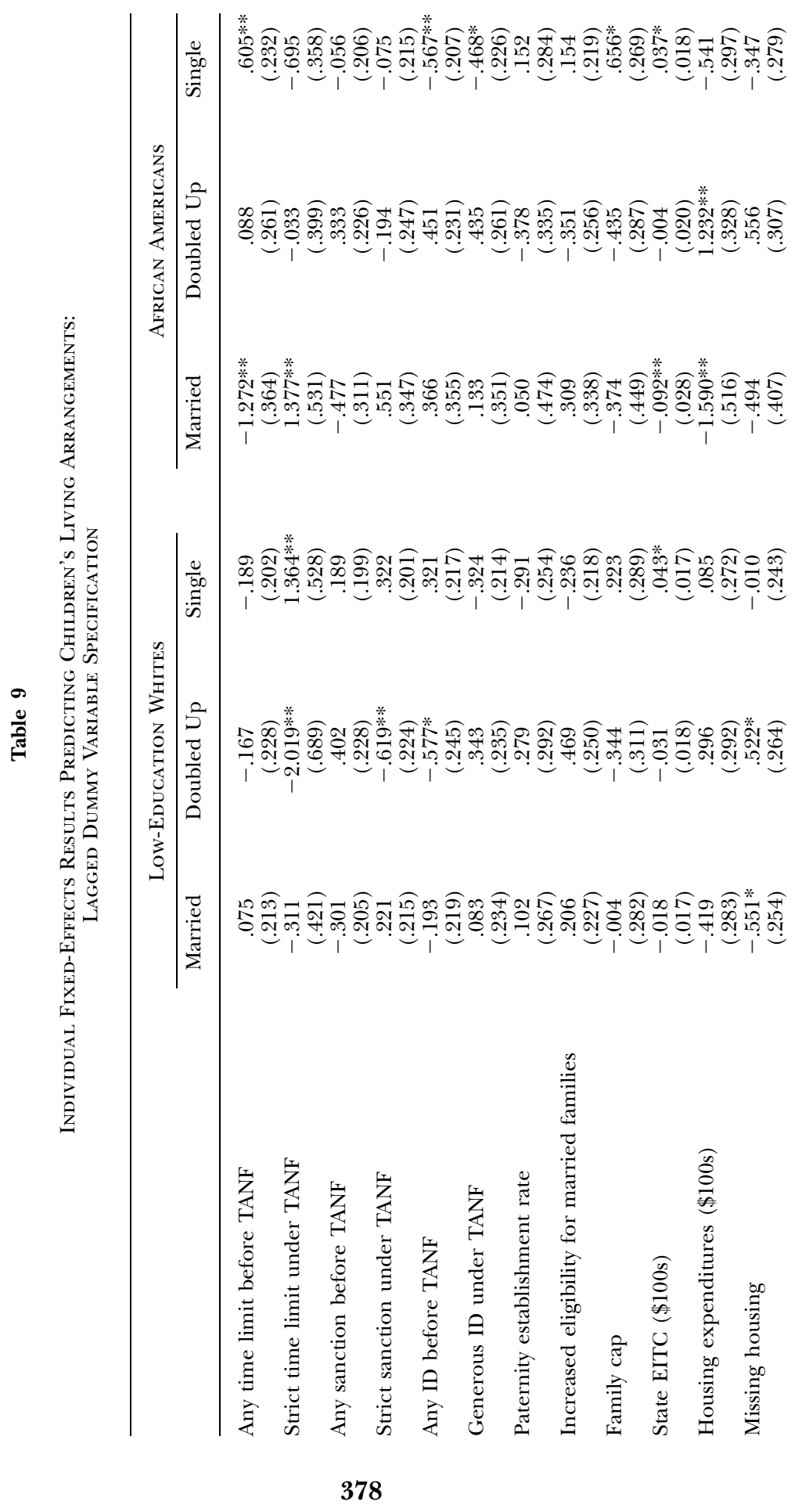




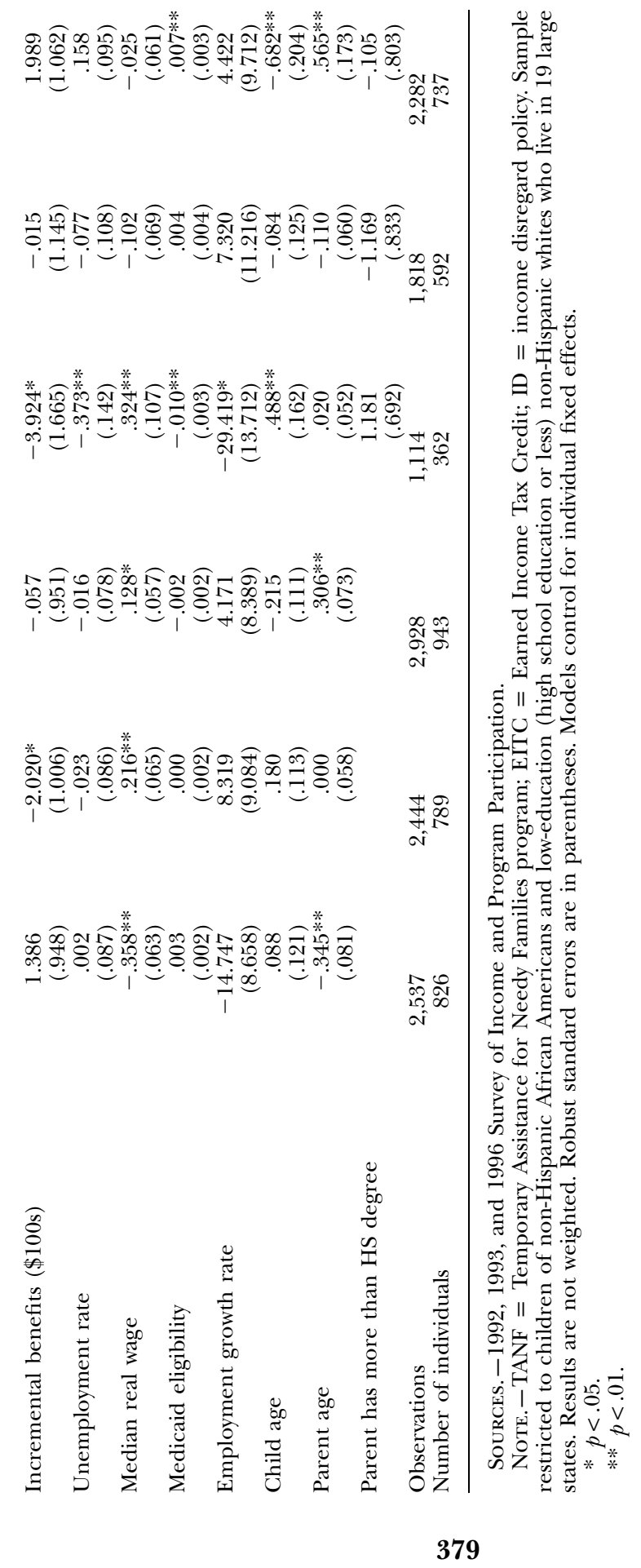




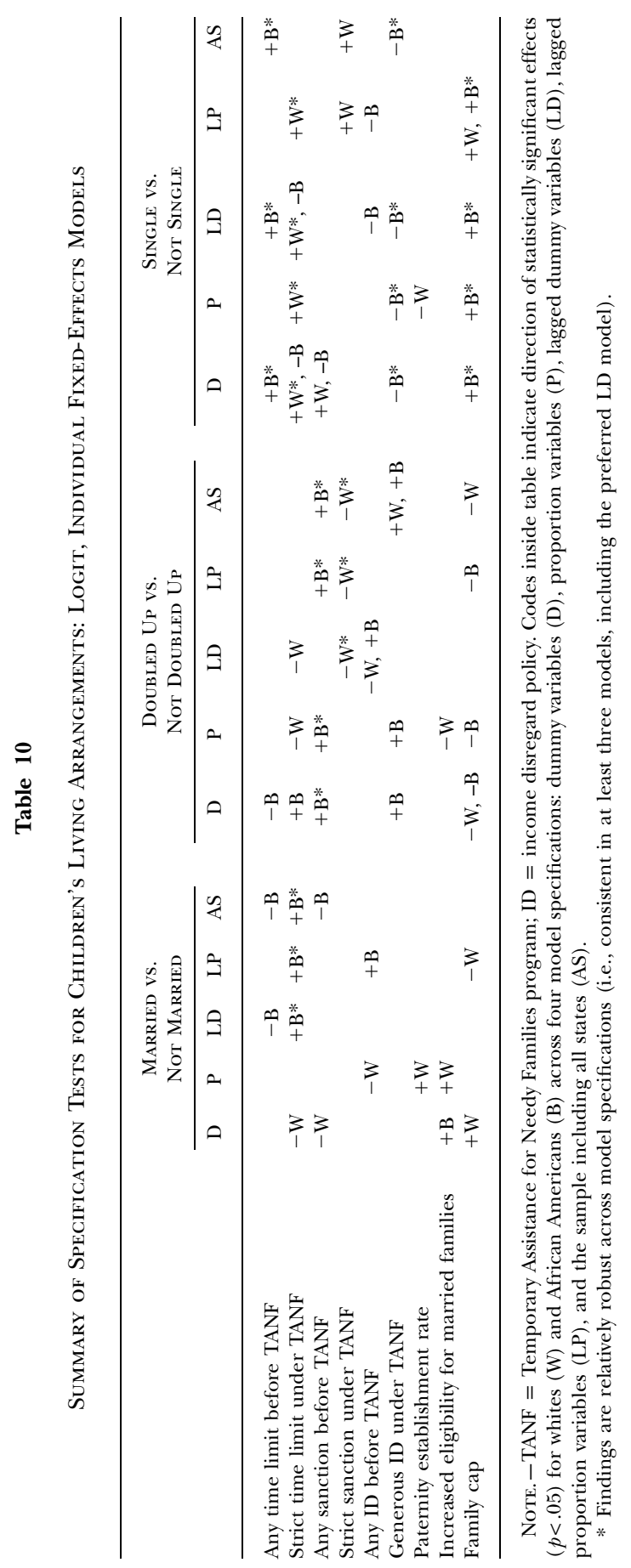


lihood that African American children live with a single parent appears to be statistically significant in table 10 , but these findings were not robust in the models that include state fixed effects.

Although changes in EITC benefits are not a focus of this study, their influence on children's living arrangements is worthy of examination. During the 1990s, state EITC benefits increased dramatically (see Schmeiser 2008). The individual fixed-effects results (table 9) show that, among white and African American children in this sample, increases in the state EITC are associated with increases in the likelihood of living with single parents. State EITC increases also are found to decrease the likelihood that African American children live in married households. The coefficients in the state fixed-effects models (table 6) operate in the same direction but are not statistically significant.

\section{Discussion}

This article examines how children's living arrangements relate to the choices states made regarding their welfare policies in the 1990s. Using SIPP data from the period between 1992 and 1999, the models rely on within-state changes in welfare policies to predict changes in children's living arrangements. This study expands on the current literature in several ways.

First, these analyses use detailed measures of welfare policy components, such as time limits, sanctions, and earning disregards, to examine the periods before and after TANF was implemented. Most previous studies employ dummy variables to indicate whether a state had any policy in effect in a given year rather than measuring specific types of policies. Second, dependent variables represent several living arrangement categories, including situations in which single parents double up with partners, their own parents, or other adults, and analyses use multinomial logistic regression models that provide insight into the transitions in children's living arrangements. Finally, the robustness of the results are thoroughly tested with an extensive series of specification tests involving both type of model (comparing cross-state and individual fixed effects) and the ways in which the policy variables were coded (lagged vs. not lagged, dummy vs. proportion variables).

Overall, the majority of the policies examined here do not show consistent associations with children's living arrangements. This includes sanctions, one of the most dramatic policy changes that occurred during the 1990s. There also is no consistent evidence that some of the policies most directly tied to children's living arrangements (specifically, family caps, states' paternity establishment rate, and policies that increase eligibility for married parents) are consistently associated with this outcome.

However, some significant associations between welfare policies and children's living arrangements are consistent across the wide range of 
models. Specifically, in states that implemented pre-TANF time limits, African American children are found to be more likely to live with a single parent than in a doubled-up household. Similarly, strict time limits under TANF are associated with an increase in the likelihood that the white children of low-education mothers (i.e., those with a high school degree or less) live with a single parent relative to the likelihood that they live in a doubled-up household. Time limits under TANF are also associated with an increase in the likelihood that African American children will live in married households. Finally, African American children in states that implemented a generous income disregard policy under TANF are found to be more likely to live in double-up households than with single parents. These findings are noteworthy in that they persist regardless of how the policy variables are coded and remain statistically significant in both the individual and state fixed-effects models.

Taken together the findings discussed above suggest that time limits, whether imposed before or under TANF, may increase the likelihood that children will live with a single mother and decrease the chances that they will live in doubled-up households. They further suggest that African American children's chances of living in a single-parent household may diminish if policies increase the income available to families (i.e., increases of the income disregard or EITC benefit). Perhaps doubling up occurs when less fortunate family members join households as mothers' income increases (e.g., due to increases in the income disregard). The additional income provided by an increase in the income disregard may also make those who receive it attractive partners for potential cohabitors (although such policies are not found to be associated with an increased likelihood of marriage). In contrast, the presence of time limits may diminish the appeal of doubling up, as mothers may be financially stressed.

Complicating the understanding of these associations is the fact that the estimated influence of various policies differs depending on the period examined. For example, only income disregards in the TANF period, and not those in the pre-TANF period, are estimated to have consistent associations with African American children's family arrangements. It is not at all clear why this would be the case. In addition, although time limits are associated with the likelihood that children live in single-parent households, this association differs by race and by time period, such that only time limits in the pre-TANF period are associated with this living arrangement for African American children. In contrast, strict time limits under TANF are associated with an increase in the likelihood that white children with low-educated mothers (those with a high school degree or less) live with a single mother but also with an increase in marriage among parents of African American children. Confidence would be highest for results that were similar in both the preTANF and TANF periods; this would indicate that implementing a par- 
ticular type of policy consistently influences living arrangement outcomes. The fact that results differ before and after TANF implementation reduces confidence in these results, even when they are consistent across various model specifications.

Because of the many ways in which this study differs from previous work, it is difficult to put these findings in context with other research in this area. In finding that there are few statistically significant and consistent associations between welfare policies and living arrangements, this study echoes the findings of Fitzgerald and Ribar (2004a, 2004b), who also use multiple SIPP panels, conduct both longitudinal and cross-sectional analyses, and examine specific types of state waiver policies. The few consistent findings in the current article are concentrated among African American children, whereas Fitzgerald and Ribar do not perform separate analyses by race.

The current findings can also be compared to those of Bitler and colleagues (2006), who find that welfare waivers are associated with a decrease in the likelihood of living with a single parent and an increase in the likelihood of living with married parents. The current study provides evidence that time limits under TANF are associated with an increase in the likelihood that African American children live in married households. There are numerous differences, however, between the current study and that by Bitler and colleagues (2006); these make it difficult to directly compare results across the two studies. Bitler and her colleagues use CPS data, which give them a larger sample and an ability to separately examine Hispanic children. The CPS data also enable them to tease out whether children in doubled-up situations live with a parent and a cohabiting partner or with a parent and grandparent. However, their main analysis does not distinguish among different types of welfare policies (the authors did test specific welfare policies, including many examined here, in some supplemental analyses, but they report no clear pattern of results). Finally, Bitler and colleagues did not use longitudinal data and thus do not estimate individual fixed-effects models.

This study has several limitations that should be considered when interpreting results. First, although analyses extensively examine the robustness of the results, the sample size is smaller than would be ideal. This is particularly true for models that subdivide the sample by race and level of education. Second, while it is important to try to parse out the effects of particular components of welfare policies (e.g., time limits and sanctions), this method may not reflect the real effect of policies on living arrangements if it is really the combination of policies that cumulatively impacts people's behavior. For instance, people's behavior may be affected differently if time limits were combined with work supports, child care vouchers, and income disregards than it would be if time limits were not implemented with these supports. Indeed, this may be one reason why findings for the pre-TANF period differ from those 
for the period after TANF's implementation. It is likely and perhaps to be expected that experimental studies of the effects of combined policy interventions on behavior may net different findings than studies that seek to isolate the effects of particular policies on behavior. In addition, it may be challenging to isolate the effect of a single policy because, for instance, a time limit may be implemented very differently across states or even across communities within states. These models will not capture that variation. Finally, the reduced-form models presented in this article provide little information about the paths through which policies influence behavior. Further research is needed to help understand the causal mechanisms underlying any observed associations.

In all, this article contributes to the understanding of the influence on children's living arrangements of changes that states made to welfare policies throughout the 1990s. It examines an extensive range of state policies and a wide set of living arrangements. It considers the robustness of results to several alternative policy specifications and utilizes both state and individual fixed-effects models. Results suggest that most examined policies have no statistically significant association with children's living arrangements. For those demonstrating associations, consistent findings vary across race and across time periods in ways that are difficult to interpret. Overall, then, these results fit with the larger body of research in this area. Such research finds little evidence that state welfare policies can influence living arrangements in ways that are large enough or consistent enough to be detected in conventional analyses. Given policy makers' interest in children's living arrangements and the expenditure of public dollars on policies designed to affect these outcomes, such research highlights the potential difficulties in using policy tools to influence such an outcome. It also suggests the need for more research on whether other types of interventions, perhaps at a smaller level, may be more effective.

\section{References}

Acs, Gregory, and Sandi Nelson. 2004. "Changes in Living Arrangements during the Late 1990s: Do Welfare Policies Matter?” Journal of Policy Analysis and Management 23 (2): 273-90.

Administration for Children and Families, Office of Child Support Enforcement (OCSE). 1994. Eighteenth OCSE Annual Report, FY1993. Washington, DC: USDHHS, Administration for Children and Families, OCSE. http://www.acf.hhs.gov/programs/cse/ pubs/archive.html\#annual.

- 1995. Child Support Enforcement Nineteenth Annual Report to Congress. Washington, DC: USDHHS, Administration for Children and Families, OCSE. http://www.acf.hhs .gov/programs/cse/pubs/archive.html\#annual.

. 1996. Child Support Enforcement Twentieth Annual Report to Congress. Washington, DC: USDHHS, Administration for Children and Families, OCSE. http://www.acf.hhs.gov/ programs/cse/pubs/archive.html\#annual.

. 1997. Child Support Enforcement Twenty-first Annual Report to Congress. Washington, DC: USDHHS, Administration for Children and Families, OCSE. http://www.acf.hhs .gov/programs/cse/pubs/archive.html\#annual. 
1998. Child Support Enforcement Twenty-second Annual Report to Congress. Washington, DC: USDHHS, Administration for Children and Families, OCSE. http://www.acf.hhs .gov/programs/cse/pubs/archive.html\#annual.

1999. Child Support Enforcement Twenty-third Annual Report to Congress. Washington, DC: USDHHS, Administration for Children and Families, OCSE. http://www.acf .hhs.gov/programs/cse/pubs/archive.html\#annual.

2000. Child Support Enforcement FY 1999 Preliminary Data Report. Washington, DC: USDHHS, Administration for Children and Families, OCSE. http://www.acf.hhs.gov/ programs/cse/pubs/2000/reports/preliminary_datareport/.

Argys, Laura M., H. Elizabeth Peters, and Donald M. Waldman. 2001. "Can the Family Support Act Put Some Life Back into Deadbeat Dads? An Analysis of Child-Support Guidelines, Award Rates, and Levels." Journal of Human Resources 36 (2): 226-52.

Bitler, Marianne P., Jonah B. Gelbach, and Hilary W. Hoynes. 2006. "Welfare Reform and Children's Living Arrangements." Journal of Human Resources 41 (1): 1-27.

Bureau of Labor Statistics. n.d. "Selected Unemployment Indicators, Seasonally Adjusted" (Table A-7). Current Population Survey, Labor Force Statistics, database. http:// www.bls.gov/webapps/legacy/cpsatab7.htm (accessed July 15, 2009).

Carlson, Marcia J., and Mary E. Corcoran. 2001. "Family Structure and Children's Behavioral and Cognitive Outcomes." Journal of Marriage and the Family 63 (3): 779-92.

Carlson, Marcia J., Irwin Garfinkel, Sara S. McLanahan, Ronald Mincy, and Wendell Primus. 2004. "The Effects of Welfare and Child Support Policies on Union Formation." Population Research and Policy Review 23 (5-6): 513-42.

Crouse, Gil. 1999. "State Implementation of Major Changes to Welfare Policies, 1992-1998." Report. http://aspe.hhs.gov/hsp/Waiver-Policies99/policy_CEA.htm.

De Jong, Gordon F., Deborah Roempke Graefe, Shelley K. Irving, and Tanja St. Pierre. 2006. "Measuring State TANF Policy Variations and Change after Reform." Social Science Quarterly 87 (4): 755-81.

Dunifon, Rachel, and Lori Kowaleski-Jones. 2002. "Who's in the House? Race Differences in Cohabitation, Single Parenthood, and Child Development." Child Development 73 (4): 1249-64.

Dyer, Wendy Tanisha, and Robert W. Fairlie. 2004. "Do Family Caps Reduce Out-of-Wedlock Births? Evidence from Arkansas, Georgia, Indiana, New Jersey and Virginia." Population Research and Policy Review 23 (5): 441-73.

Fitzgerald, John M., and David C. Ribar. 2004a. "Transitions in Welfare Participation and Female Headship." Population Research and Policy Review 23 (5): 641-70.

- 2004b. "Welfare Reform and Female Headship." Demography 41 (2): 189-212.

Foster, E. Michael, and Ariel Kalil. 2007. "Living Arrangements and Children's Development in Low-Income White, Black, and Latino Families." Child Development 78 (6): $1657-74$.

Garfinkel, Irwin, Daniel S. Gaylin, Chien-Chung Huang, and Sara S. McLanahan. 1998. "Will Child Support Enforcement Reduce Nonmarital Childbearing?" Unpublished manuscript. Princeton University, Princeton, NJ.

Gassman-Pines, Anna, Hirokazu Yoshikawa, and Sandra Nay. 2006. "Can Money Buy You Love? Dynamic Employment Characteristics, the New Hope Project, and Entry into Marriage." 206-32 in Making It Work: Low-Wage Employment, Family Life, and Child Development, edited by Hirokazu Yoshikawa, Thomas S. Weisner, and Edward D. Lowe. New York: Russell Sage.

Gennetian, Lisa A. 2005. "One or Two Parents? Half or Step Siblings? The Effect of Family Structure on Young Children's Achievement." Journal of Population Economics 18 (3): 415-36.

Gennetian, Lisa A., and Virginia Knox. 2003. "Staying Single: The Effects of Welfare Reform Policies on Marriage and Cohabitation.” Next Generation Working Paper no. 19. MDRC, New York.

Gennetian, Lisa A., and Cynthia Miller. 2004. "How Welfare Reform Can Affect Marriage: Evidence from an Experimental Study in Minnesota." Review of Economics and the Household 2 (3): 275-301.

Ginther, Donna K., and Robert A. Pollak. 2004. "Family Structure and Children's Educational Outcomes: Blended Families, Stylized Facts and Descriptive Regressions." Demography 41 (4): 671-96.

Graefe, Deborah Roempke, Gordon F. De Jong, and Shelley K. Irivng. 2006. "The Whole 
Is the Sum of Its Parts: Theory, Technique, and Measurement Science Applied to TANF Rules." Social Science Quarterly 87 (4): 818-27.

Grogger, Jeffrey, and Lynn A. Karoly. 2005. Welfare Reform: Effects of a Decade of Change. Cambridge, MA: Harvard University Press.

Grogger, Jeffrey, and Charles Michalopoulos. 2004. "Welfare Dynamics under Time Limits." Journal of Political Economy 111 (3): 530-54.

Harknett, Kristen S., and Lisa A. Gennetian. 2003. "How an Earnings Supplement Can Affect Union Formation among Low-Income Single Mothers." Demography 40 (3): 451-78.

Harper, Cynthia C., and Sara S. McLanahan. 2004. "Father Absence and Youth Incarceration." Journal of Research on Adolescence 14 (3): 369-97.

Horvath-Rose, Ann E., and H. Elizabeth Peters. 2001. "Welfare Waivers and Nonmarital Childbearing." 222-44 in For Better and for Worse: Welfare Reform and the Well-Being of Children and Families, edited by Greg J. Duncan and P. Lindsay Chase-Lansdale. New York: Russell Sage.

Horvath-Rose, Ann E., H. Elizabeth Peters, and Joseph Sabia. 2008. "Capping Kids: The Family Cap and Nonmarital Childbearing." Population Research and Policy Review 27 (2): 119-38.

Hoynes, Hilary W. 1997. "Does Welfare Play Any Role in Female Headship Decisions?" Journal of Public Economics 65 (2): 89-117.

Joyce, Ted, Robert Kaestner, Sanders Korenman, and Stanley Henshaw. 2004. "Family Cap Provisions and Changes in Births and Abortions." Population Research and Policy Review 23 (5): 475-511.

Leigh, Andrew. 2003. "Who Benefits from the Earned Income Tax Credit? Incidence among Recipients, Coworkers and Firms." Working Paper, November, Harvard University, Kennedy School of Government, Cambridge, MA.

McLanahan, Sara S., and Gary Sandefur. 1994. Growing Up with a Single Parent: What Hurts, What Helps. Cambridge, MA: Harvard University Press.

Moffitt, Robert A. 1998. "The Effect of Welfare on Marriage and Fertility." 50-97 in Welfare, the Family, and Reproductive Behavior: Research Perspectives, edited by Robert A. Moffitt. Washington, DC: National Academy Press.

Murray, Charles A. 1984. Losing Ground: American Social Policy, 1950-1980. New York: Basic.

National Center for Health Statistics. n.d. "Vital Stats: Demographic Characteristics of Mother by State/County, 1992-1999." http://205.207.175.93/VitalStats/Report Folders/reportFolders.aspx (accessed July 15, 2009).

National Governors Association. 2001. "Maternal and Child Health (MCH) Update: States Have Expanded Eligibility and Increased Access to Health Care for Pregnant Women and Children." Issue Brief, February 22. National Governors Association, Health Policy Studies Division, Washington, DC. http://www.nga.org/Files/pdf/ MCHUPDATE2000.pdf.

National Research Council, Panel on Data and Methods for Measuring the Effects of Changes in Social Welfare Programs. 2001. Evaluating Welfare Reform in an Era of Transition, edited by Robert A. Moffitt and Michele Ver Ploeg. Washington, DC: National Academy Press.

Nixon, Lucia A. 1997. "The Effect of Child Support Enforcement on Marital Dissolution." Journal of Human Resources 32 (1): 159-81.

Peters, H. Elizabeth, Laura M. Argys, Heather Wynder Howard, and J. S. Butler. 2004. "Legislating Love: The Effect of Child Support and Welfare Policies on Father-Child Contact." Review of Economics of the Household 2 (3): 255-74.

Peters, H. Elizabeth, Robert D. Plotnick, and Se-Ook Jeong. 2003. "How Will Welfare Reform Affect Childbearing and Family Structure Decisions?" 59-94 in Changing Welfare, edited by Rachel A. Gordon and Herbert J. Walberg. New York: Klumer Academic/Plenum.

Plotnick, Robert D., Inhoe Ku, Irwin Garfinkel, and Sara S. McLanahan. 2001. "The Impact of Child Support Enforcement Policy on Nonmarital Childbearing." Paper presented at the 2001 Population Association of America conference, March, 2001, Washington DC.

Ryan, Suzanne, Jennifer Manlove, and Sandra L. Hofferth. 2006. "State-Level Welfare Policies and Nonmarital Subsequent Childbearing." Population Research and Policy Review 25 (1): 103-26. 
Schmeiser, Maximilian D. 2008. "Expanding New York State's Earned Income Tax Credit Program: The Effect on Work, Income, and Poverty." Discussion Paper no. 1341-08. University of Wisconsin, Institute for Research on Poverty, Madison.

Schoeni, Robert F., and Rebecca M. Blank. 2000. "What Has Welfare Reform Accomplished? Impacts on Welfare Participation, Employment, Income, Poverty, and Family Structure." Working Paper no. 7627. National Bureau of Economic Research, Cambridge, MA.

Tax Policy Center. 2009. "Earned Income Tax Credit Parameters, 1975-2009." Table, April 22. Urban Institute and Brookings Institution, Washington, DC. http://www .taxpolicycenter.org/taxfacts/displayafact.cfm?Docid $=36$.

Urban Institute. n.d. "Welfare Rules Database." Urban Institute, Washington, DC. http:// www.urban.org/Content/Research/NewFederalism/Data/ANFData.htm (accessed September 2004).

U.S. Census Bureau. 1993. Federal Expenditures by State for Fiscal Year 1992. Report no. FES/ 92, March. Washington, DC: U.S. Government Printing Office.

. 1994. Federal Expenditures by State for Fiscal Year 1993. Report no. FES/93RV, April. Washington, DC: U.S. Government Printing Office.

. 1995. Federal Expenditures by State for Fiscal Year 1994. Report no. FES/94, March. Washington, DC: U.S. Government Printing Office.

- 1996. Federal Expenditures by State for Fiscal Year 1995. Report no. FES/95-RV, September. Washington, DC: U.S. Government Printing Office. http://www.census.gov/ prod/2/gov/fes95rv.pdf.

- 1997. Federal Expenditures by State for Fiscal Year 1996. Report no. FES/96, April. Washington, DC: U.S. Government Printing Office. http://www.census.gov/prod/2/ gov/fes-96.pdf.

- 1998. Federal Expenditures by State for Fiscal Year 1997. Report no. FES/97, April. Washington, DC: U.S. Government Printing Office.

. 1999. Federal Aid to States for Fiscal Year 1998. Report no. FAS/98, April. Washington, DC: U.S. Government Printing Office. http://www.census.gov/prod/99pubs/fas98.pdf.

- 2000. Federal Aid to States for Fiscal Year 1999. Report no. FAS/99, April. Washington, DC: U.S. Government Printing Office. http://www.census.gov/prod/2000pubs/fas99.pdf.

2001. Federal Aid to States for Fiscal Year 2000. Report no. FAS/00, April. Washington, DC: U.S. Government Printing Office. http://www.census.gov/prod/2001pubs/fas00.pdf.

USDHHS (U.S. Department of Health and Human Services), Office of the Assistant Secretary for Planning and Evaluation. 1997. "Setting the Baseline: A Report on State Welfare Waivers.” Report, June. http://aspe.hhs.gov/hsp/isp/waiver2/title.htm.

Wallace, Geoffrey L. 2009. "The Effects of Family Caps on the Subsequent Fertility Decisions of Never-Married Mothers.” Journal of Population Research 26 (1): 73-101.

Westat and Mathematica Policy Research. 2001. Survey of Income and Program Participation Users' Guide. 3rd ed. Washington, DC: U.S. Department of Commerce, Economics and Statistics Administration, U.S. Census Bureau. http://www.census.gov/sipp/usrguide/ sipp2001.pdf.

Zaslow, Martha, Kathryn Trout, Christopher Botsko, and Kristin Moore. 1998. "Welfare Reform and Children: Potential Implications.” New Federalism: Issues and Options for States Report no. A-23. Urban Institute, Washington, DC. http://www.urban.org/ url.cfm? ID $=308014$

\section{Notes}

An earlier version of this article was presented at the 2005 meetings of the Population Association of America. This research is supported by a grant to the first author from the National Institute of Child Health and Human Development (1 R03 HD43890-01). We would like to thank Greg Acs, Kosali Simon, and Geoffrey Wallace for providing policy data, and Heather Howard, Wenni Lee, Jacqueline Vanderpuye-Orgle, and Felicia Yang 
for data assistance. We are grateful for helpful comments from Marianne Bitler and Wayne Osgood.

1. Analysis begins in 1992 because the first state waivers were not implemented until the end of 1992 (Crouse 1999).

2. The 1992 panel includes 21,577 households surveyed over 10 waves from February 1992 through May 1995. The 1993 panel includes 21,823 households surveyed over 9 waves from February 1993 through January 1996. The 1996 panel includes 40,188 households surveyed over 13 waves from April 1996 through March 2000.

3. Thirty-nine percent of the African American child spells have a parent with more than a high school degree, but the remaining 6,295 spells of children with less educated parents would not provide a large enough number of spells in each outcome group across states and years.

4. Respondent loss (at the household level) by the end of the SIPP panels was 26.6 percent for the 1992 panel, 26.9 percent for the 1993 panel, and 35.5 percent for the 1996 panel (Westat and Mathematica 2001).

5. Sample size issues preclude a separate examination of cohabiting mothers. They represent about one-third of the doubled-up group for both African American and white children. This means that only a handful of cohabiting mothers are represented in each state and year.

6 . The term "parent" refers to the person identified as the child's parent (typically mother). If the mother's information is not available, analyses use information on the household head. Only 29 observations have a parent whose age is over 65 .

7. The TANF proportion variable is coded zero in years before the state implemented TANF, one in years after TANF was implemented, and is the proportion of the year in which TANF was implemented for the year that the state implemented TANF. The waiver variables in the pre-TANF period (time limit, sanction, income disregard) are similarly coded: instead of being coded one in the year the state implemented the waiver, they are coded as the proportion of the year the state had the waiver in place. In the year TANF was implemented (and thereafter), these variables were coded one in the dummy variable specification. In the proportion models, these waiver variables are coded as the maximum of either the proportion of the year the waiver was in place or the proportion of the year TANF was in place. To capture the proportion of the year a state had a strict policy in effect in the TANF period, analyses assume that the strict policy was implemented at the same time as TANF. Therefore, the measure of strict sanctions, for example, equals the proportion of the year TANF was in place in the first year that the strict policy began and then one for each year thereafter that the policy was in place. The authors are unable to create proportion measures for policy strictness or generosity after this initial implementation year. 